drug trafficking, as forces beyond Bolivia's borders shape prices, demand, and availability of cocaine. Almost half the cocaine paste and refined powder seized in Bolivia seeps in from Peru through 650 miles of sparsely populated and monitored border. The Morales administration has aggressively pursued cocaine paste and refined cocaine, achieving record seizures over several years. It also staunchly opposes drug decriminalization or legalization.

Peru still pursues forced eradication with U.S. financing, and the divergence from Bolivia's current orientation could not be sharper. "Forced eradication might be the catalyst that fuels violence and social conflict among the rural Quechua and mestizo peoples, who still suffer the trauma of the 1980's and 1990's armed conflict. Criminal groups could take advantage of this situation to provoke conflict between the rural population, the government and the armed forces," says former Peruvian drug czar, Ricardo Soberón. Colombia also continues to rely on forced eradication, including damaging aerial fumigation with a high human toll, continued conflict and negative environmental impact. Although Colombia forcibly eradicates an average of over 100,000 hectares a year, its coca crop is still double that of Bolivia's.

Increased citizenship rights for Bolivia's growers has fostered unprecedented acceptance of the once-hated rural antidrug police (UMOPAR). "Now the military, UMOPAR, and the government work with the unions, and we have good coordination. The massacres and torture have come to an end," says Marcela López of the Women's Federation.

It has become harder to find places to manufacture cocaine paste as well because growers fear losing their cato if paste operations are discovered on their land. Community control has "been bad for the cocaine business," says the former director of the anti-drug police, Gonzalo Quezada. "The growers themselves turn in traffickers, something they never did before."

Brazil, now the world's second-largest paste and cocaine consumer, buys almost $80 \%$ of Bolivia's production. The 2,000 mile border through tropical wilderness and isolated scrubland make control close to impossible. Nonetheless, in November 2012, the Bolivian, Brazilian, and Peruvian governments formed a working group to systematize control efforts and to address drug over-flights between their countries.

Bolivian government and participating growers

\title{
Challenging Myths About \\ Chapare Coca Paste Production
}

\section{THOMAS GRISAFFI}

Bolivia's second-most important coca growing region, the Chapare, is often cast in both local and international media as the principal hub of the local drug trade. Coca leaf farmers are described as 'nouveau riche' peasants who spend their ill-gotten druog gains on luxury cars, parties, and houses. And it is not just the pressex-President Jorge Quiroga recently accused the Chapare Agricultural Federations, and by extension the

Thomas Grisaffi is an Anthropologist; he is currently working as a post-doctoral research fellow at the UCL Institute of the Americas in London.
Morales government, of protecting the illicit trade.

Such images and myths belie the harsh reality of drug production and trafficking. Bolivia perches on the lowest rung of the international trade, mostly fabricating low-value coca paste (the first step in manufacturing cocaine) at sites scattered throughout the country. Most drug workers (known as Pichicateros) are young men without land or much hope of decent jobs, not unionized Chapare coca growers.

Pichicateros labor in rudimentary operations to soak shredded coca leaf in solvents that extract the cocaine alkaloid. The lure of fast money and the chance to amass enough to escape grinding poverty and buy a rusty old taxi or a patch of land is usually what drives them. Some become addicted to smoking paste cigarettes (known as pitillos) and find themselves trapped working in the trade to ensure their access to drugss. Their living conditions are poor; most of their houses are made of rough-cut planks without running water, sanitation, or electricity.

They earn about $\$ 30$ a day (agricultural labor pays less than half that) for work that is tedious, irregular, and harmful to their health. It is also very risky: if caught, they face eight years in prison. During a research trip to the Chapare in October 2013 I asked a 14 year-old pisa-coca (coca stomper) about his work. He described wading around in a toxic stew of coca, gasoline, and acid for several hours a day. 
see it as a matter of national pride to be responsible international partners in the drug control efforts. "This government helped raise our awareness that we couldn't grow more coca, not just because it is illegal, but also because it would give our country a bad international image," declares Yungas grower Juan Mamani.

Given Bolivia's history of bureaucratic inefficiency, community control's results are impressive. Faced with a significant funding gap in 2013 and 2014, the concept's persistence reflects growers' organizational strength, trust, and loyalty. Yungas union leader Elias Cruz insists that even a year after funding stopped, "community control remains in force, not as an institution, but in the conscience of producers."

Community coca control, for all its inevitable limitations, has proven more effective and cost efficient than forced eradication, and represents a sovereign, local initiative appropriate to its context. By permitting farmers to grow a small amount of the product they rely on for economic survival, combined with participatory monitoring, improved government services, economic development initiatives, and a reduction in violent repression, growers are in a better position to diversify their production base and limit their dependence on an illicit crop.

"Results from a policy as innovative as this are not going to be immediate," contends former Chapare Human Rights Ombudsman, Godofredo Reinicke. "There will be successes and failures, ups and downs, but community control of coca needs to be given sufficient time to see if it makes sense as a sustainable approach to reducing drug-related violence." $\mathbf{n}$
The fumes gave him a terrible headache and his flimsy rubber boots let in acid that turned his toe nails green.

Local coca growers worry about the trade's harmful impact on their communities, even though local consumption of illicit druggs remains very low. In an interview carried out in January 2014 one woman told me: "Pichicata, it's just so ugly. I want my son to go to university. I worry about him being tempted by the cash and pitillos."

While previous governments treated the six Chapare coca grower federations as criminal organizations, the Morales administration has had considerable success in enlisting them as partners in the fight against trafficking. For eight years, the federations have made concerted efforts to tackle paste production with local-level union leaders, organizing frequent commissions to check that none of their members are involved. If a functioning or even abandoned production site is discovered, the union has the power to confiscate the culprit's land and expel him or her from the community. The federation coordinates closely with the anti-druog police, and union members frequently denounce people in charge of paste production. The guilty 'factory' owner faces up to 15 years in prison.

When Bolivia still adhered to the failed U.S. prohibitionist policies, pichicateros could process base paste close to the main roads and towns, safe in the knowledge that their neighbors were unlikely to report them to the authorities. U.S.-financed repression against growers effectively convinced all Chapare residents that the police were enemies. But this is no longer the case. One pichicatero lamented: "Before, the compas (coca growers) would tell you when the
UMOPAR (anti-drug police) were coming. Now they just turn you in."

This heightened pressure from within the coca-growing community has changed pichicatero behavior. They now set up production in ever more remote areas and rarely maintain an operation in one site for more than two weeks - lest people get suspicious. That the pichicateros go to such lengths to hide their activity from the coca growers provides solid evidence of the Federations' commitment to actively reject drug trafficking.

While coca-cocaine represents a signnificant segment of Bolivia's economy, paste producers are certainly not the major beneficiaries. But the country's grinding poverty means there will always be those willing to assume the substantial risks in what is often the slim hope of building a better future. $\mathbf{n}$ 